\title{
INTERVENING CONDITIONS ON GOVERNANCE OF THE NURSING PRACTICE AT AN OBSTETRICS CENTRE ${ }^{a}$
}

\begin{abstract}
Roberta Juliane Tono de OLIVEIRA ${ }^{\mathrm{b}}$, Fernanda Hannah da Silva COPELLIc ${ }^{\mathrm{c}}$, Aline Lima PESTANA ${ }^{\mathrm{d}}$, José Luís Guedes dos SANTOS ${ }^{e}$, Vitória Regina Petters GREGÓRIO ${ }^{f}$, Alacoque Lorenzini ERDMANNo
\end{abstract}

\section{ABSTRACT}

Governance refers to all processes that grant nurses autonomy, control and authority over the nursing practice. The aim of this study was to identify intervening conditions on governance of nursing practice at an obstetrics centre. This is a qualitative study based on the Grounded Theory method. Data were collected between January and May 2013 by means of semi-structured interviews with 27 participants of a university hospital in southern Brazil, divided into four sampling groups. Data were analysed using open, axial and selective coding. Governance is reinforced by experience and professional autonomy, coordination of the care and management dimension, interpersonal communication, satisfaction and engagement with the profession. It is limited by difficulties with interpersonal relationships, work overload and precarious physical structure of the maternity units. This study provides arguments for the discussion on improvements in healthcare and the professional satisfaction of nurses and nursing teams.

Descriptors: Management. Obstetrical nursing. Clinical governance. Healthcare management.

\section{RESUMO}

A governança relaciona-se aos processos que conferem aos enfermeiros autonomia, controle e autoridade sobre a prática de enfermagem. Este estudo objetivou identificar as condições intervenientes à governança da prática de enfermagem no centro obstétrico. Pesquisa qualitativa que utilizou como referencial metodológico a Teoria Fundamentada nos Dados. A coleta de dados ocorreu entre janeiro e maio de 2013, por meio de entrevistas semiestruturadas com 27 participantes de um Hospital Universitário do sul do Brasil, divididos em quatro grupos amostrais. A análise dos dados foi realizada mediante codificação aberta, axial e seletiva. A governança é potencializada pela experiência e autonomia profissional, articulação da dimensão assistencial e gerencial, comunicação interpessoal, satisfação e envolvimento com a profissão. E é limitada pela dificuldade de relacionamento interpessoal, sobrecarga de trabalho e estrutura física precária dos setores da Maternidade. O estudo oferece subsídios para a discussão sobre a melhoria do cuidado e da satisfação profissional entre enfermeiros e equipe de enfermagem.

Descritores: Gerência. Enfermagem obstétrica. Governança clínica. Gestão em saúde.

Título: Condições intervenientes à governança da prática de enfermagem no centro obstétrico.

\footnotetext{
a Article based on the research project "Best management practices in hospital environment: governance and standards of nursing and healthcare", funded by the Universal Calling - MCTI/CNPq N 14/2012, process \#474644/2012-0.

b Nurse. Master's degree student of Nursing of the Graduate Nursing Programme at the Federal University of Santa Catarina (PEN/UFSC). Florianópolis, Santa Catarina, Brazil.

c Nurse. Master's degree student of Nursing of the PEN/UFSC. Florianópolis, Santa Catarina, Brazil.

d Nurse. PhD student of the PEN/UFSC. Scholarship student of the National Council for Scientific and Technological Development (CNPq). Florianópolis, Santa Catarina, Brazil.

e Nurse. PhD in Nursing. Junior Postdoctoral scholarship student of the CNPq and PEN/UFSC. Florianópolis, Santa Catarina, Brazil.

f Nurse. PhD in Nursing. Associate Professor of the UFSC Department of Nursing. Florianópolis, Santa Catarina, Brazil.

g Nurse. PhD in Philosophy of Nursing. Full Professor of the UFSC Department of Nursing. 1A scholarship student of the CNPq. Florianópolis, Santa Catarina, Brazil.
} 


\section{RESUMEN}

Gobernanza refiere a procesos que confieren a los enfermeros autonomía, control y autoridad sobre la práctica de enfermería. Este estudio objetivó identificar condiciones que intervienen en la gobernanza de enfermería en el centro de obstetricia. Estudio cualitativo utilizó como metodología la teoría fundamentada. Los datos fueron recolectados de enero a mayo de 2013, a través de entrevistas con 27 participantes de un hospital universitario en el sur de Brasil, divididos en cuatro grupos de muestreo. Los datos fueron analizados usando codificación abierta, axial y selectiva. La gobernanza se potencia por la experiencia de los enfermeros, percepción de autonomía, articulación entre cuidado y gerencia, comunicación interpersonal, satisfacción y compromiso profesional. La dificultad en las relaciones interpersonales, sobrecarga de trabajo y precariedad de la estructura fisica fueron identificados como limitantes de la gobernanza. El estudio proporciona subsidios para mejorar la calidad de la atención y la satisfacción laboral del personal de enfermería.

Descriptores: Gerencia. Enfermería obstétrica. Gestión clínica. Gestión en salud.

Título: Condiciones que intervienen en la gobernanza de la práctica de enfermería en el centro de obstetricia.

\section{INTRODUCTION}

Nurses in the scope of an Obstetrics Centre $(\mathrm{OC})$ execute, as in other practice scenarios, care and management activities. The provision of care comprises early labour, childbirth and postnatal assistance to ensure full attention to health of the mother and the newborn child. Nursing care in this context involves physical examination, anamnesis and monitoring of fetal heart rate ${ }^{(1)}$.

Management activities consist of preparing monthly and weekly reports, organizing sectors and teams, distribution and supervision of staff and respective activities, nursing evolution, and registration of records and childbirth numbers, to enable full organization of the workload. Consequently, management activities of nurses target the forecasting and provision of recourses, delegation of functions, planning and supervision of actions, permanent team education, staff dimensioning, performance assessments, systemizing nursing care, and other activities ${ }^{(2-6)}$.

The dimensions of care and management were historically considered dichotomous in the work of nurses. However, studies ${ }^{(2-3,5)}$ have shown the complementarity and interdependence of care and management, since the management activities of nurses seek to ensure the quality of nursing care. To separate these activities would compromise this quality and may generate conflicts in the work of nurses. Consequently, from the standpoint of indissolubility between management and care, new methods of providing healthcare and managing work processes have been discussed for public policies of the Ministry of Health. To the different collective groups and teams, these policies propose the challenge of overcoming limitations and experience new forms of organizing services and new ways of producing care ${ }^{(7)}$.

Among the recent models that have been discussed in the area of nursing management, one of the most noteworthy is the concept of governance. Nursing governance is related to the processes that grant autonomy in the nursing practice in an organization or healthcare service to improve the quality of care $^{(8)}$.

Interest on this topic emerges due to a shortage of studies that discuss aspects that facilitate or hinder governance on the professional practice of nurses. Consequently, research was based on the following question: How do nurses define aspects that facilitate and hinder governance of the nursing practice at an obstetrics centre?

The aim of this study was to identify intervening conditions on governance of the nursing practice at an obstetrics centre. The concept is based on the fact that greater governance of nurses in relation to care management activities contribute to the improvement of provided care and increase the professional satisfaction of nurses.

\section{METHOD}

This is a qualitative study based on the Grounded Theory method (GT) of data analysis ${ }^{(9)}$. The study was conducted at a public university hospital in the southern region of Brazil. Participants were selected after being indicated by interviewees, according to the following inclusion criteria: minimum three-month experience in the sector, underwent training to adapt to the unit, and availability to participate in this study. Exclusion 
criteria were: on sick leave or any other work leave during the study period. There were no exclusions.

Theoretical sampling consisted of four sample groups (SG). The $1^{\text {st }} \mathrm{SG}$ (E1-E8) comprised eight nurses of the obstetrics centre (OC), with experience that ranged from 2 and 18 years. The $2^{\text {nd }} \mathrm{SG}$ (E9-E15) was formed by seven nurses of Obstetrics/Gynaecological Screening and Joint Accommodation with 1 to 19 years of experience in the department. The $3^{\text {rd }} \mathrm{SG}$ (E16-E21) consisted of six professionals of the healthcare team, of which three were nursing technicians, one was a nursing assistant and two were obstetrics medical residents, with experiences in the sector that ranged from 2 and 18 years. The $4^{\text {th }} \mathrm{SG}$ (E22-E27) consisted of six management nurses of the $\mathrm{UH}$, with which relevant aspects stated by nurses of the $1^{\text {st }} \mathrm{SG}$ were explored. Sample size was determined by theoretical saturation of data, totalling 27 interviews.

Data were collected by means of individual semi-structured interviews recorded in a digital device at the work location or another location chosen by the participants, from January to May 2013. Interviews were fully transcribed with an average duration of 50 minutes. Data collection and analysis were simultaneous. The comparative analysis method was used to study data ${ }^{(9)}$.

Coding occurred concurrently in three stages: open, axial and selective coding. Open coding was the first data analysis stage and consisted of separating, examining, comparing and conceptualizing obtained data. During this stage, data were analysed line by line so that each interview statement was transformed into codes. These codes were then grouped according to similarities and differences. Grouped codes formed subcategories, labelled according to the respective topics. The second analysis stage was axial coding, in which data were grouped again to create the categories. The last stage, titled selective coding, consisted of searching for and creating the central category that encompassed all the other categories ${ }^{(9)}$.

The study was based on use of the pragmatic model that aims to establish an explicative relationship between categories and sub-categories, identifying them as phenomena, context, casual conditions, intervening conditions, strategies and consequences $^{(9)}$. This analysis process established by the TFD produced inter-categories that, when interrelated, support the phenomenon: "Gover- nance emerging from the professional practice of nurses based on the exercise of control over the care environment of the obstetrics centre, the command of scientific knowledge and on professional experience" ${ }^{10}$. This article presents the component of intervening conditions.

Ethical aspects were observed according to resolution \#196/96 of the National Health Council. This study was submitted and approved by the Human Research Ethics Committee of the Federal University of Santa Catarina (CEP/UFSC), opinion \#242.944/2013. Method and objective of this study were explained to all participants, who then agreed to the interviews and signed a consent form. Confidentiality was preserved by identifying each participant with the initial letter "E" followed by the ordinal number of each interview.

\section{RESULTS AND DISCUSSION}

The two categories that illustrate intervening conditions are: Enumerating contributing elements of governance and Governance limited by organizational and relational barriers. Figure 1 shows the interconnection between these categories and the detected phenomenon. Each of the categories is listed below.

\section{Enumerating contributing elements of governance}

Several aspects contribute to the governance of nurses at the OC. Statements mostly reveal issues related to scientific knowledge, professional experience, perception of professional autonomy, coordination of the care and management dimension, interpersonal communication and professional satisfaction.

Scientific knowledge, professional experience and recognition of the academic education of nurses by the healthcare team are the most notable facilitators of the emergence of governance in the context of maternity sectors. This recognition and years of experience help nurses to maintain their practice within the context of an OC.

Contributing factors of my governance are my scientific knowledge, my experience, my personality [...] (E6).

Here we have an advantage because almost all the nurses are obstetrics nurses or have experience in obstetrics, so 


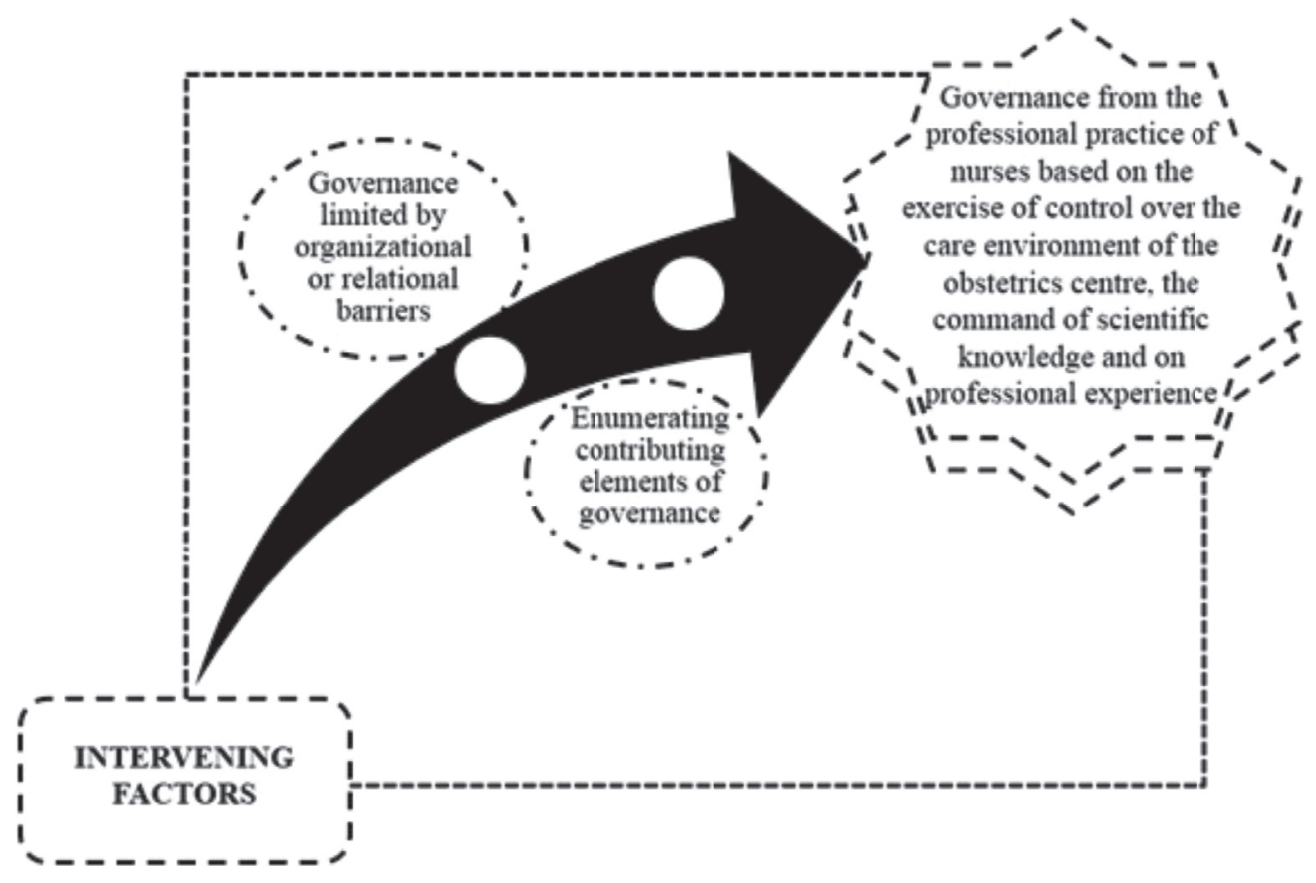

Figure 1-Graphic representation of intervening factors on the detected phenomenon. Florianópolis, SC, 2013.

Source: Produced by authors

they truly perform that role of governance, of managing each shift (E2O).

At first, I was really insecure, I didn't know anything, but the hospital itself taught me things and I managed to learn a lot in here (E25).

Literature shows that scientific knowledge is an important tool for the obtainment of governance because it provides the support for decision-making among nurses. Similarly, professional experience provides greater certainty and wisdom for the practice of nursing ${ }^{(11)}$. Studies show that professional experience tends to create greater governance because it allows the nurse to feel more confident and consequently make decisions more easily. Furthermore, experienced nurses have a higher level of empowerment as a result of greater knowledge and experience than recently graduated nurses, with the added benefit of being able to predict situations they have already experienced ${ }^{(12-13)}$.

When questioned about the governance they exercise, nurses stated personal and professional autonomy to conduct their work in the context of an OC. Many nurses answered that there was no limiting factor on their governance considering that they had full autonomy in the work environment, as revealed in the statements below.

I have always had autonomy in the obstetrics centre (E5).

During our shift, we have full autonomy, in my own area of expertise and knowledge, obviously [...]. But in my area of expertise we have full autonomy that is granted by management of the maternity hospital and nurses management (E8).

We have full autonomy to detect what is happening and make the necessary decisions to solve problems [...]. No one comes here to interfere with our work (E23).

In their statements, the nurses related their autonomy to their professional knowledge and competencies, and the support provided by the nursing management of the institution. This support is a fundamental factor in the process of building autonomy and empowerment of the nursing staff ${ }^{(19)}$.

The term governance was also widely related to unit control and the professional practice of nurses, especially in relation to coordination between management and care. 
That is precisely what allows us to control the unit, because if you only focus on administration, you miss out on most of the care activities [...]. I think that the best way for a nurse with a management position to develop his or her role is providing care, because that is where you realize what is happening and the best form of intervention (E5).

Emphasis on unit control as a facilitating factor for coordinating care and management of the nursing practice corroborates and reinforces findings of previous studies that reveal the indissolubility of these two areas of professional practice ${ }^{(2-3)}$.

Meetings were mentioned as favouring interpersonal relationships and managing conflicts. Therefore, participants considered meetings as facilitating conditions of governance and important instruments for decision-making.

I think that meetings reinforce our work. I have been working at the UH for more than 30 years and from the very beginning, we have always tried to strengthen the team through meetings [...] I think it's the best strategy for nurses to express their ideas (E5).

We already have a monthly meetings schedule, when we can express our difficulties, or anything that needs attention. During our meetings we make decisions, write a document that we all sign and submit to management [...] management cannot work alone, under any circumstances; it must have the support of our nursing staff and middle management (E4).

According to the interviewees, interpersonal relationships are strengthened during meetings through the exchanging knowledge, discussing difficulties and searching for ways to solve the presented problems. Communication at the OC was mild and not loud, which facilitated interpersonal relationships and consequently promoted governance. Previous studies show that the communication process is considered a management tool, revealing that communication is a strategy to ensure the successful management of nursing care. Communication is therefore essential in interpersonal relationships because it enables the exchanging of information, ideas, facts and orders, reduces differences and narrows the gap between people with the same objectives. These studies also show that the administrative restructuring that resulted in shared management models promotes the valorisation of teamwork and interpersonal relationships ${ }^{(14-15)}$.
Professional satisfaction based on identification with the profession, pleasure in the work environment and contentment with the provided care were also facilitating factors of governance.

I have been in this profession for thirty years and I love what I do. I always say that the only things I learned how to do well in life were being a mother and being a nurse (E8).

Pleasure in my work is important to me, not to just come here for the sake of it, it is working associated with pleasure so that I don't become an ill-tempered, stressed person and a bad professional (E15).

The professional satisfaction that the nurses mentioned allowed them to perform their activities in a more pleasant manner, with less stress, which is reflected in the quality of their patient care. Similarly, a previous study also identified the association between job satisfaction and quality of patient care $^{(16)}$.

\section{Governance limited by organizational and relational barriers}

According to the statements, limiting aspects that hinder the emergence of governance in the OC include difficulties in establishing interpersonal relationships, work overload and precariousness of physical structures in the maternity units.

Difficulties in establishing interpersonal relationships between employees of different sectors generate conflicts and personal disputes. When these conflicts are not dealt with, they compromise professional satisfaction and the provided care.

I have really difficulties in establishing relationships with other sectors! It is difficult for me to receive patients from screening when I don't have room here and nurses need to bring them here [...]. We are having serious problems with nurses from Neonatal Care, because of the babies with serious complications (E3).

Working in teams can sometimes be very difficult because they are very resistant to changes. We try to identify the problems and bring the team here to solve these problems, but we aren't always successful (E26).

Interpersonal relationships, especially conflicting relationships, were constantly mentioned during the interviews for this study. 
Organizations are political structures that are consequently permeated with personal interests that potentially generate conflict. Nurses must realize that organizational conflicts are inevitable, and can be reduced but never eliminated. Eliminating conflict should not be the objective, but rather finding alternatives to solve conflict that can lead to change. One of the competencies that nurses need in order to achieve governance is the capacity to recognize and manage conflict in the hospital environment ${ }^{(17-18)}$.

Another aspect that tended to hinder the control that nurses had over their practice is work overload, mainly triggered by increased patient flow and staff shortages.

When there are lots of patients, it is very hard to control the environment [...]. We obviously don't provide the same care when we are not occupied with a single birth $(E 1)$.

Increased demand, a good relationship with other nurses of the other units, shortage of professionals also limit my control (E1O).

Work overload caused by increased demand and shortage of professionals was mentioned by the interviewees as being another aspect that hinders governance. Work overload generates personal demands, physical exhaustion and frustration because nurses cannot conduct their work as desired. This work overload is perceived as a factor that causes anguish among nurses, leading to discouragement and dissatisfaction in their professional practice ${ }^{(19)}$.

Precariousness of the sector structure was also mentioned as being an intervening factor of control:

[...] the physical structure is really trashed, everything is improvised and that is terrible. I like working here in the OC, but it gets complicated because of the work flow and because the unit is in such bad shape (E2).

How to accommodate these clients sometimes bothers me and can be stressful [...] it really limits the things I would like to do, and, for example, sometimes when receiving patients we don't have a wheelchair to offer mothers-to-be. In that sense, it is very limiting (E12).

According to the interviewees, aspects that hinder governance are related to the organizational environment/context, while subjective/psycho- logical issues were considered components that favour governance. Consequently, nurses hoped for structural changes to achieve governance, keeping in mind that governance was related to the power to propose structural changes in the unit and not merely limited to subjective issues. Similarly, a previous study detected the desire of employees for institution managers to allow improvements and changes in hospital units that could create a more favourable work environment for patients and the healthcare team ${ }^{(20)}$.

In the statements above, nurses showed interest in providing better quality care. However, the fragile physical structure and shortage of equipment often hindered the provision of adequate and humanized care.

\section{FINAL CONSIDERATIONS}

This investigation allowed the identification of factors that interfere with governance of nurses in the context of an OC, represented by the categories: Enumerating contributing elements of governance and Governance limited by organizational and relational barriers, that integrate the phenomenon "Governance emerging from the professional practice of nurses based on the exercise of control over the care environment of the obstetrics centre, on the command of scientific knowledge and on professional experience".

As a result, governance is the nurse's ability to control his or her professional practice and know the aspects that promote or compromise this control over the work environment. Governance is empowered by the professional nursing practice, perception of professional autonomy, coordination of the care and management dimension, interpersonal communication and satisfaction and engagement with the profession. On the other hand, factors related to difficulties in establishing interpersonal relationships, work overload and precariousness of the physical structures of maternity units were identified as factors that limited governance of the nursing practice.

In this study, it is important to emphasize the inconsistency in relation to interpersonal relationships, which were considered both positive and negative. This could be related to the inherent complexity of social and professional relationships at work and the early stages of shared gover- 
nance detected in the investigated environment. Although nurses tried to establish horizontal relationships with the nursing team, there was still a strong technical and social organization of work in hierarchical positions and levels within the institution.

It should be considered that studies on the topic of governance are still incipient in the context of Brazilian Nursing, considering that healthcare services are mostly based on organizational models that focus on traditional management precepts. Consequently, governance can be considered a strategy to explore in the discussion on the implementation of shared management models that favour team engagement in the decision-making processes of the institution, thus contributing to improvements in the provided care and professional satisfaction of nurses and nursing teams.

Study results have limited generability because data were collected in a single study context. There were also difficulties when discussing results, since the topic in question has not been widely explored in Brazil. We therefore suggest new studies on governance in other nursing practice scenarios that can identify and discuss practices and strategies related to nursing governance, enable greater autonomy and professional satisfaction for nurses and improve care practices in the health services.

\section{REFERENCES}

1 Gregorio VRP, Padilha MI. As estratégias do poder no contex to da maternidade Carmela Dutra: Florianópolis-SC (1956-1986). Texto Contexto Enferm. 2012;21(2):277-85.

2 Rossi FR, Silva MAD. Fundamentos para processos gerenciais na prática do cuidado. Rev Esc Enferm USP. 2005;39(4):460-8.

3 Hausmann M, Peduzzi M. Articulação entre as dimensões gerencial e assistencial do processo de trabalho do enfermeiro. Texto Contexto Enferm. 2009; 18(2):258-65.

4 Winck DR, Brüggemann OM. Responsabilidade legal do enfermeiro em obstetrícia. Rev Bras Enferm. 2010;63(3):464-9.

5 Felli VEA, Peduzzi M. O trabalho gerencial em enfermagem. In: Kurcgant P, coordenadora. Geren- ciamento em enfermagem. Rio de Janeiro: Guanabara Koogan; 2010. p.1-13.

6 Santos RB dos, Ramos KS. Sistematização da assistência de enfermagem em centro obstétrico. Rev Bras Enferm. 2012;65(1):13-8.

7 Ministério da Saúde (BR), Secretaria de Atenção à Saúde, Política Nacional de Humanização da Atenção e Gestão do SUS. Gestão participativa e cogestão. Brasília (DF); 2009.

8 Bennett PN, Ockerby C, Begbie J, Chalmers C, Hess RG Jr, O'Connell B. Professional nursing governance in a large Australian health service. Contemp Nurse. 2012;43(1):99-106.

9 Strauss A, Corbin J. Pesquisa qualitativa: técnicas e procedimentos para o desenvolvimento da teoria fundamentada. 2. ed. Porto Alegre: Artmed; 2008.

10 Copelli FHS, Oliveira RJT. Governança da prática de enfermagem no centro obstétrico de um hospital universitário [monografia]. Florianópolis (SC): Universidade Federal de Santa Catarina; 2013.

11 Dale JC, Drews B, Dimmitt P, Hildebrandt E, Hittle K, Tielsch-Goddard A. Novice to expert: the evolution of an advanced practice evaluation tool. J Pediatr Health Care. 2013;27(3):195-201.

12 Overcash J, Petty LJ, Brown S. Perceptions of shared governance among nurses at Midwestern Hospital. Nurs Adm Q. 2012;35(4):E1-E11.

13 Laschinger HK, Wong CA, Grau AL. Authentic leadership, empowerment and burnout: a comparison in new graduates and experienced nurses. J Nurs Manag. 2013;21(3):541-52.

14 Santos JLG, Prochnow AG, Lima SBS, Leite JL, Erdmann AL. Concepções de comunicação na gerência de enfermagem hospitalar entre enfermeiros gerentes de um hospital universitário. Rev Esc Enferm USP. 2011;45(4):959-65.

15 Santos MC, Bernardes A. Comunicação da equipe de enfermagem e a relação com a gerência nas instituições de saúde. Rev Gaúcha Enferm. 2010;31(2):359-66.

16 Faulkner J, Laschinger H. The effects of structural and psychological empowerment on perceived respect in acute care nurses. J Nurs Manag. 2008; 16(2):214-21. 
17 Guerra ST, Prochnow AG, Trevizan MA, Guido LA. O conflito no exercício gerencial do enfermeiro no âmbito hospitalar. Rev Lat-Am Enfermagem. 2011;19(2):362-9.

18 Scherb CA, Specht JK, Loes JL, Reed D. Decisional involvement: staff nurse and nurse manager perceptions. West J Nurs Res. 2011;33(2):16179 .
19 Santos JLG, Prochnow AG, Silva DC, Silva RM, Leite JL, Erdmann AL. Prazer e sofrimento no exercício gerencial do enfermeiro no contex to hospitalar. Esc Anna Nery. 2013;17(1):97-103.

20 Moura GMSS, Inchauspe JAF, Dall'Agnol CM, Magalhães AMM, Hoffmeister LV. Expectativas da equipe de enfermagem em relação à liderança. Acta Paul Enferm. 2013;26(2):198-204.

\author{
Author's address / Endereço do autor / \\ Dirección del autor \\ Roberta Juliane Tono de Oliveira \\ Centro de Ciências da Saúde, Bloco I, Sala de estu- \\ dos $1,4^{\circ}$ andar, Trindade \\ 88040-900, Florianópolis, SC \\ E-mail: roberta_tono@hotmail.com
}

Received: 15.10.2013

Approved: 04.02.2014

Versão on-line em Português/Inglês: http://www.scielo.br/ scielo.php?script $=$ sci_serial\&pid $=1983-1447 \& \operatorname{lng}=$ pt\&nrm $=$ iso 